\title{
Market, Freedom and the Illusions of Microcredit. Patronage, Caste, Class and Patriarchy in Rural South India
}

\author{
ISABELLE GUÉRIN**** \& SANTOSH KUMAR**
}

*IRD-Cessma, Université Paris Diderot - CESSMA, Paris, France, **French Institute of Pondicherry, Pondicherry, India

\section{Online Appendix}

The following tables summarise and quantify the various forms of data collected in this research, given that only a small part of it is used in the paper, but it is of course impossible to only extract the data that has been used in the paper.

Table A.1. Household surveys

\begin{tabular}{|c|c|c|}
\hline & Sampling ${ }^{\text {a }}$ & Main focus \\
\hline 2010 Survey & 407 households & Labour and financial practices \\
\hline $\begin{array}{l}\text { Villipuram and Cuddalore } \\
\text { districts }\end{array}$ & $\begin{array}{l}\text { Representative sample of the } \\
\text { local population }\end{array}$ & \\
\hline 2008 Survey & 170 households & The gender of financial practices (an analysis of \\
\hline $\begin{array}{l}\text { Tiruvallur and Vellore } \\
\text { districts }\end{array}$ & $\begin{array}{l}\text { Representative sample of } \\
\text { microcredit clientele }\end{array}$ & women and their financial practices) \\
\hline 2006 Survey & 344 households & Over-indebtedness and microcredit \\
\hline $\begin{array}{l}\text { Villipuram and Cuddalore } \\
\text { districts }\end{array}$ & $\begin{array}{l}\text { Representative sample of the } \\
\text { local population }\end{array}$ & \\
\hline $\begin{array}{l}\text { 2004-06-09 Survey } \\
\text { (longitudinal analysis) }\end{array}$ & $\begin{array}{l}395 \text { households } \\
\text { Representative sample of }\end{array}$ & Over-indebtedness and microcredit \\
\hline
\end{tabular}

Source: Authors'

Notes: ${ }^{\text {a }}$ For all our household surveys, sampling was stratified by caste and location (dry/irrigated, and proximity to urban centres). 
Table A.2. Qualitative data collection

\begin{tabular}{ll}
\hline Semi-directive interviews & NGO or MFI managers (30) \\
& Loan officers (30) \\
& Local politicians (15) \\
& Elected local officials (15) \\
& Informal moneylenders (15) \\
& Women (148) \\
Group discussions with villagers & Men (36) \\
& Loan officers (6) \\
Case studies (in addition to semi- & SHG leaders (11) \\
directive interviews) & Microcredit organisations: around 12 months spent in their offices or with \\
Participant Observation & the staff in the field. \\
& Village life: around 36 months spent in villages, in Dalit and non-Dalit \\
& settlements \\
& 24 media events: \\
& Women's day (8) \\
& March against alcoholism (1), against atrocities to women (1), request for \\
& financial compensation after flooding (1) \\
& Health awareness campaigns (4) \\
& NGOs coordination meeting at the district level (2) \\
& Politician visit (3) \\
SHG exhibition (3) \\
March against the Iraq war (1)
\end{tabular}

Source: Authors'

Table A.3. Microcredit organisations' features

\begin{tabular}{|c|c|c|c|c|}
\hline & Mission & Services & Number of SHG & Funding \\
\hline NGO A (1986) & $\begin{array}{l}\text { Facilitate community- } \\
\text { based actions among } \\
\text { marginalised and poor } \\
\text { communities }\end{array}$ & $\begin{array}{l}\text { Women's development } \\
\text { (microfinance) } \\
\text { Child rights and } \\
\text { empowerment } \\
\text { Empowerment of } \\
\text { persons with } \\
\text { disabilities } \\
\text { Environment, sanitation } \\
\text { and health }\end{array}$ & $\begin{array}{l}1435 \text { SHG } \\
21,182 \text { women } \\
\quad(2012)\end{array}$ & $\begin{array}{l}\text { Government of India } \\
\text { Six agencies from the } \\
\text { Tamil Nadu State } \\
\text { International Labour } \\
\text { Organisation }\end{array}$ \\
\hline NGO B (1993) & Rural development & $\begin{array}{l}\text { Community health } \\
\text { Women's } \\
\text { empowerment } \\
\text { (Microfinance, } \\
\text { entrepreneurship } \\
\text { training) } \\
\text { Welfare and relief }\end{array}$ & $\begin{array}{l}\text { Around } 1800 \\
\text { SHG, 25,200 } \\
\text { women } \\
(2012)\end{array}$ & $\begin{array}{l}\text { Mother organisation } \\
\text { based in Chennai } \\
\text { Private donations } \\
\text { Tamil Nadu Women } \\
\text { Development } \\
\text { Corporation }\end{array}$ \\
\hline NGO C (1990) & $\begin{array}{l}\text { Rural community } \\
\text { development, with a } \\
\text { specific focus on } \\
\text { women and children }\end{array}$ & $\begin{array}{l}\text { Community health } \\
\text { Women's } \\
\text { empowerment } \\
\text { (Microfinance, } \\
\text { entrepreneurship } \\
\text { training) }\end{array}$ & $\begin{array}{l}102 \text { SHG } \\
1632 \text { women } \\
(2012)\end{array}$ & $\begin{array}{l}\text { Private donations } \\
\text { Tamil Nadu Women } \\
\text { Development } \\
\text { Lutheran network }\end{array}$ \\
\hline
\end{tabular}


Table A.3. (Continued)

\begin{tabular}{|c|c|c|c|c|}
\hline & Mission & Services & Number of SHG & Funding \\
\hline NGO D (1969) & $\begin{array}{l}\text { Social services for the } \\
\text { poor and the } \\
\text { marginalised }\end{array}$ & $\begin{array}{l}\text { Women's } \\
\text { empowerment } \\
\text { (microfinance) } \\
\text { Community } \\
\text { development } \\
\text { Education through } \\
\text { evening studies }\end{array}$ & $\begin{array}{l}4472 \text { SHG } \\
56,819 \text { women } \\
\quad(2012)\end{array}$ & $\begin{array}{l}\text { Caritas } \\
\text { French and German } \\
\text { foundations } \\
\text { LIC company } \\
\text { Tamil Nadu Women } \\
\text { Development } \\
\text { Corporation }\end{array}$ \\
\hline NGO E & $\begin{array}{l}\text { To restore the human } \\
\text { dignity of the poor, } \\
\text { the deprived and the } \\
\text { marginalised toward } \\
\text { sustainable } \\
\text { development and a } \\
\text { process of } \\
\text { empowerment }\end{array}$ & $\begin{array}{l}\text { Socioeconomic } \\
\text { development and } \\
\text { livelihood support } \\
\text { (microfinance) } \\
\text { Child education } \\
\text { Community based } \\
\text { disaster preparedness } \\
\text { Housing } \\
\text { Home for the mentally } \\
\text { ill }\end{array}$ & $\begin{array}{l}\text { Around } 3600 \\
\text { SHGs, 56,400 } \\
\text { women } \\
\text { (2012) }\end{array}$ & $\begin{array}{l}16 \text { foreign partners; } \\
\text { including various } \\
\text { branches of Caritas, } \\
\text { foundations, } \\
\text { international } \\
\text { organisations like } \\
\text { IFAD and UNDP }\end{array}$ \\
\hline NGO F (1989) & $\begin{array}{l}\text { Empowering poor rural } \\
\text { women/youth/farmers/ } \\
\text { fisherman/artisans/ } \\
\text { disabled persons to } \\
\text { become economically } \\
\text { self-sustainable and } \\
\text { independent decision- } \\
\text { makers in the family } \\
\text { as well as in society }\end{array}$ & $\begin{array}{l}\text { Microfinance } \\
\text { Education and } \\
\text { sensitisation } \\
\text { Health services, water } \\
\text { and sanitation } \\
\text { Housing programmes }\end{array}$ & $\begin{array}{l}400 \text { SHG } \\
6000 \text { women } \\
(2010)\end{array}$ & $\begin{array}{l}7 \text { foreign funders } \\
\text { Various Tamil Nadu } \\
\text { state agencies }\end{array}$ \\
\hline $\begin{array}{l}\text { MFI A } \\
\text { (created as an } \\
\text { NGO in } \\
1985 \text {, and } \\
\text { then } \\
\text { transformed } \\
\text { into an MFI } \\
\text { in 2003) }\end{array}$ & $\begin{array}{l}\text { Empowerment through } \\
\text { financial inclusion } \\
\text { 'Financial inclusion i.e. } \\
\text { delivery of financial } \\
\text { services at affordable } \\
\text { costs to sections of } \\
\text { disadvantaged and } \\
\text { low-income segments } \\
\text { of society and linking } \\
\text { of the poor to } \\
\text { mainstream financial } \\
\text { services is the key to } \\
\text { empowerment' }\end{array}$ & $\begin{array}{l}\text { Microfinance services } \\
\text { Sister organisations } \\
\text { provide education } \\
\text { group training, } \\
\text { capacity building, } \\
\text { livelihood training, } \\
\text { microenterprise } \\
\text { development and } \\
\text { support, marketing of } \\
\text { member products, } \\
\text { bank and institutional } \\
\text { linkage, exposure } \\
\text { visits, information } \\
\text { dissemination }\end{array}$ & $\begin{array}{l}148,000 \text { active } \\
\text { borrowers in } \\
2013\end{array}$ & $\begin{array}{l}\text { Loans from the Indian } \\
\text { government, financial } \\
\text { institutions and banks } \\
\text { like RMK, SIDBI, } \\
\text { VGB, SBT, IOB, } \\
\text { FWWB, HDFC, } \\
\text { Dhanalakshmi Bank, } \\
\text { CORDAID, RABO } \\
\text { Bank Foundation }\end{array}$ \\
\hline $\begin{array}{l}\text { MFI B, started } \\
\text { in } 2005\end{array}$ & $\begin{array}{l}\text { Providing microfinance } \\
\text { services to women } \\
\text { from poor segments of } \\
\text { urban and rural Tamil } \\
\text { Nadu }\end{array}$ & Microfinance services & $\begin{array}{l}360,000 \text { clients } \\
\text { in } 2013\end{array}$ & $\begin{array}{l}15 \text { Indian banks, } 2 \\
\text { foreign banks (BNP } \\
\text { and ING), investment } \\
\text { fund equity partners }\end{array}$ \\
\hline
\end{tabular}

Source: Authors 


\section{NGOs and Patronage Networks}

Here we set out three different examples of the diversity of alliances NGOs have to build in order to survive, and the role of media events within them.

The first NGO, which we shall to refer to as NGO A, was founded by two brothers who were both Catholic, but from a middle caste background. It targets local populations as a whole, without caste or religious distinction. It is very close to the government, whatever the ruling power. It has also received foreign funding through Catholic networks, which are very active in the Indian NGO world. An NGO staff member is almost always posted in the district collector's office at the local authorities, which guarantees the NGO - and its members - privileged access to public schemes. In addition, NGO A plays an informal brokering role for many small NGOs who lack the contacts and know-how to access local administrations. All of these come with expected paybacks. The NGO is required to actively contribute to the launch and success of governmental schemes. This entails selecting members, ensuring sufficient take-up, coordinating with the press and then regularly organising media events to ensure schemes' visibility. The NGO is also required to regularly mobilise women so they attend the ruling power's political rallies: the women are told that this is the price to pay to enjoy the wide range of services offered by the NGO. For these events, NGO A can also rely on the women representatives of the small NGOs for which it acts as a broker. Exchanging groups is another form of dealing: NGO A gives its support to small NGOs and gets new SHGs in return (Dalit SHGs in particular, as the NGO is often struggling to reach them). We also came across the opposite case: NGO A offers some of its SHGs to strengthen an NGO which is too small to be eligible for governmental schemes.

The second NGO B is much smaller and defines itself as a community-based organisation created by and for Dalit women. It has very close relationships to the Lutheran church through its founder, who is a female pastor. She has helped many Dalit families to convert to Protestantism, while providing them with services, first with health and education, and now microcredit. Her sources of funding are irregular and she is always struggling to access public schemes. As a result, she heavily depends on NGO A above. In exchange, she has to send 'her' women to the media events NGO A organises. She had long refused to organise her own public events, arguing that the women had much better things to do with their time and that they should not be used as puppets for politicians. Exasperated by her dependency on NGO A, and humiliated for not being recognised for her own work, she thus began to organise her own 'women's day'. The first one she organised, in 2008, gathered around 450 women and a few local personalities. She said that this was much less than NGO A (around 1500 women, more than 10 local personalities) but that it was fairly satisfactory given the small size of her organisation.

Both NGOs moreover maintain close relationships with a local branch of a Dalit party (Ambedkhar People Front). These two NGOs operate in Thiruvallur district, which is well known for the relative political strength of its Dalit population. Their relative upward mobility has created a climate of hostility with non-Dalits. The slightest focal point, such as NGO or governmental benefits, can raise tensions and conflict with non-Dalits. Linking up with Dalit associations is a way for NGOs to prevent an escalation of violence. Here too, the mobilisation of women for mass events is a key aspect of the collaboration. When the Dalit association settles local conflicts, NGOs send buses of women for mass meetings of the Dalit association in return.

The third NGO operates in the district of Vellore, which has a more typically agrarian political structure. Agriculture is still very important here, and so high castes retain a high degree of dominance. NGO C has its origins in the urban upper class elite, being created by a Brahmin family based in the state capital of Chennai. It is funded in a variety of ways but private donations and international grants are the most common sources. While this NGO initially focused on health, it has gradually extended its activities to rural development, including microcredit. It has regularly held mass events, on health for the most part (awareness campaigns, detection tests for HIV-aids, cancer, and so forth). Women are required to attend these events whether they are useful to them or not. The events are sponsored by Chennai businessmen (for instance a Jain network of jewellers) and doctors, some of whom we met, and who are convinced that they are doing good, unaware that the women may not want or need to 
participate. For these donors to invest in social events is a means to lower their taxes, but also to boost their social image and gain popularity. Some come personally to inaugurate the event and may have their photograph in the newspapers. To sustain links to rural areas through sponsorship is a very common strategy for building a reputation as a public benefactor. The high caste network is also key to the NGO becoming established locally. Unlike Thiruvallur, where NGOs often have to make alliances with Dalit associations, in this case, to make high caste alliances helps to guarantee a strong local presence (or is at least a possible strategy, which NGO C pursues). Such alliances may take official channels such as donations (which are publically displayed at the NGO's headquarters and at all of the NGO's events) or membership of the NGO board. Alliances may also be informal, for example with local high caste families (mostly Mudaliars here) systematically being consulted for approval for any new activities.

Table A.4. Microcredit use

\begin{tabular}{|c|c|c|c|}
\hline & $\begin{array}{l}\text { Average } \\
\text { microcredit } \\
\text { amount (INR) }\end{array}$ & $\begin{array}{l}\text { Income-generating } \\
\text { activities primary } \\
\text { use }\end{array}$ & Other uses \\
\hline 2010 Survey & 10,000 & $9.9 \%$ & $\begin{array}{l}\text { Family expenses }(57 \%) \text {, loan repayment }(9.3 \%) \text {, housing } \\
(7.3 \%) \text {, health }(6 \%) \text {, ceremonies }(5.9 \%) \text {, education } \\
(4.6 \%)\end{array}$ \\
\hline 2008 Survey & 6100 & $4 \%$ & $\begin{array}{l}\text { Ceremonies }(24 \%) \text {, housing }(22 \%) \text {, loan repayment } \\
(15 \%) \text {, health }(11 \%) \text {, education }(7 \%) \text { other }(7 \%)\end{array}$ \\
\hline 2006 Survey & 12,800 & $26 \%$ & $\begin{array}{l}\text { Ceremonies }(14 \%) \text {, daily life }(23 \%) \text {, loan repayment } \\
(6 \%) \text {, health }(10 \%) \text {, education }(11 \%) \text {, housing }(4 \%) \text {, } \\
\text { other }(6 \%)\end{array}$ \\
\hline 2004 Survey & 5,000 & $19 \%$ & $\begin{array}{l}\text { Loan repayment }(26 \%) \text {, health }(19 \%) \text {, daily life }(14 \%) \text {, } \\
\quad \text { education }(10 \%) \text {, ceremonies }(5 \%) \text {, other }(7 \%)\end{array}$ \\
\hline
\end{tabular}

Source: Authors' surveys

Notes: The data presented here was collected from a total of 1316 households

Table A.5. Profile of loan officers and SHG leaders

\begin{tabular}{|c|c|c|c|c|}
\hline $\begin{array}{l}\text { Gender, age (in } \\
2014), \\
\text { education, } \\
\text { caste and } \\
\text { religion }\end{array}$ & $\begin{array}{l}\text { Role in } \\
\text { microcredit } \\
\text { organisations and } \\
\text { main occupation } \\
\text { (for SHG leaders) }\end{array}$ & Networks & Additional services & $\begin{array}{l}\text { Accumulation } \\
\text { (rough estimate) }\end{array}$ \\
\hline $\begin{array}{l}\text { M1, Male } \\
42 \text { years old } \\
\text { Secondary } \\
\text { education } \\
\text { Middle caste } \\
\text { (Vanniyar) }\end{array}$ & Loan officer & $\begin{array}{l}15 \text { years' experience in } \\
\text { social work } \\
\text { Network with local banks, } \\
\text { private companies, local } \\
\text { Vanniyar community } \\
\text { association (local contact } \\
\text { of the PMK, the } \\
\text { Vanniyar party) }\end{array}$ & $\begin{array}{l}\text { Moneylending } \\
\text { Microinsurance } \\
\text { Advice on personal matters }\end{array}$ & $\begin{array}{l}\text { Moneylending: } \\
\text { net profit of } \\
15,000 \mathrm{INR} \\
\text { per month } \\
(2013)\end{array}$ \\
\hline
\end{tabular}


Table A.5. (Continued)

\begin{tabular}{|c|c|c|c|c|}
\hline $\begin{array}{l}\text { Gender, age (in } \\
2014) \text {, } \\
\text { education, } \\
\text { caste and } \\
\text { religion }\end{array}$ & $\begin{array}{c}\text { Role in } \\
\text { microcredit } \\
\text { organisations and } \\
\text { main occupation } \\
\text { (for SHG leaders) }\end{array}$ & Networks & Additional services & $\begin{array}{l}\text { Accumulation } \\
\text { (rough estimate) }\end{array}$ \\
\hline $\begin{array}{l}\text { M2, Male } \\
44 \text { years old } \\
\text { Highly } \\
\text { educated } \\
\text { (Master in } \\
\text { social work) } \\
\text { Dalit Hindu }\end{array}$ & Loan officer & $\begin{array}{l}20 \text { years' experience of } \\
\text { social work (literacy } \\
\text { campaigns, health } \\
\text { campaigns, then } \\
\text { microcredit and income- } \\
\text { generating activities) } \\
\text { Network with local } \\
\text { administrations, } \\
\text { moneylenders } \\
\text { Strongly involved in the } \\
\text { Dalit Panthers party }\end{array}$ & $\begin{array}{l}\text { Government schemes and } \\
\text { administrative paper } \\
\text { work } \\
\text { Moneylending } \\
\text { Advice on health services, } \\
\text { schooling, } \\
\text { personal matters }\end{array}$ & $\begin{array}{l}\text { Moneylending } \\
\text { net profit of } \\
7500 \text { INR per } \\
\text { month (2013) }\end{array}$ \\
\hline $\begin{array}{l}\text { M3, Male } \\
\text { Around } 45 \\
\text { Secondary } \\
\text { education, } \\
\text { and trained } \\
\text { in alternative } \\
\text { medicine } \\
\text { sidha } \\
\text { Middle caste } \\
\text { (Vanniyar), } \\
\text { HIndu }\end{array}$ & Loan officer & $\begin{array}{l}25 \text { years' experience of } \\
\text { social work (literacy and } \\
\text { health campaign) } \\
\text { Networks with } \\
\text { administrative offices, } \\
\text { hospitals, moneylenders, } \\
\text { trade unions and } \\
\text { Ambedkhar People Front } \\
\text { (Dalit party) }\end{array}$ & $\begin{array}{l}\text { Government schemes } \\
\text { Health services (traditional } \\
\text { healer) } \\
\text { Advices for school, } \\
\text { personal matters } \\
\text { Moneylending } \\
\text { Microinsurance }\end{array}$ & $\begin{array}{l}\text { Information not } \\
\text { available }\end{array}$ \\
\hline $\begin{array}{l}\text { F4, Female } \\
50 \text { years old } \\
\text { Secondary } \\
\quad \text { education } \\
\text { Dalit Christian } \\
\quad \text { (Protestant) }\end{array}$ & Loan officer & $\begin{array}{l}\text { Through her husband, } \\
\text { network with local } \\
\text { administrations and } \\
\text { governmental schemes } \\
\text { Part of the Lutheran church } \\
\text { preaching group } \\
\text { Connection with a Dalit } \\
\text { movement trough her } \\
\text { husband (Dalit Panthers) }\end{array}$ & $\begin{array}{l}\text { Government schemes and } \\
\text { administrative paper } \\
\text { work } \\
\text { Advice on health services, } \\
\text { legal issues and personal } \\
\text { matters }\end{array}$ & $\begin{array}{l}\text { Microinsurance } \\
\text { agent: net } \\
\text { profit of } \\
\text { around } 5000 \\
\text { per year (2013) }\end{array}$ \\
\hline $\begin{array}{l}\text { F5, Female } \\
48 \text { years old } \\
\text { Secondary } \\
\text { education } \\
\text { Dalit Hindu }\end{array}$ & Loan officer & $\begin{array}{l}20 \text { years' experience in } \\
\text { social work } \\
\text { Good network with local } \\
\text { banks, moneylenders }\end{array}$ & $\begin{array}{l}\text { Moneylending } \\
\text { Advice on personal matters }\end{array}$ & $\begin{array}{l}\text { Moneylending: } \\
\text { net profit of } \\
5000 \text { to } 7000 \\
\text { per month } \\
\text { (2013) }\end{array}$ \\
\hline $\begin{array}{l}\text { F6, Female } \\
65 \text { years old } \\
\text { Primary } \\
\quad \text { education } \\
\text { Dalit Christian } \\
\quad \text { (protestant) }\end{array}$ & Loan officer & $\begin{array}{l}35 \text { years' experience of } \\
\text { social work } \\
\text { Networks with local } \\
\text { administrations and } \\
\text { informal lenders }\end{array}$ & $\begin{array}{l}\text { Government schemes and } \\
\text { administrative paper } \\
\text { work } \\
\text { Advices for health services } \\
\text { and personal matters } \\
\text { Microinsurance } \\
\text { Rosca } \\
\text { Moneylending }\end{array}$ & $\begin{array}{l}\text { Information not } \\
\text { available }\end{array}$ \\
\hline $\begin{array}{l}\text { F7, Female } \\
50 \text { years old } \\
\text { Secondary } \\
\quad \text { education } \\
\text { Dalit Christian } \\
\quad \text { (Catholic) }\end{array}$ & $\begin{array}{l}\text { SHG leader } \\
\text { Moneylending }\end{array}$ & $\begin{array}{l}\text { Through her husband } \\
\text { (retired teacher), strong } \\
\text { relationships with caste } \\
\text { leaders in the village } \\
\text { Labour recruiter for local } \\
\text { landowners }\end{array}$ & $\begin{array}{l}\text { Government schemes and } \\
\text { administrative paper } \\
\text { work } \\
\text { Moneylending } \\
\text { Labour }\end{array}$ & $\begin{array}{l}\text { Moneylending: } \\
\text { net profit of } \\
30,000 \text { to } \\
40,000 \text { per } \\
\text { month } \\
\text { (January 2011) }\end{array}$ \\
\hline
\end{tabular}


Table A.5. (Continued)

\begin{tabular}{|c|c|c|c|c|}
\hline $\begin{array}{l}\text { Gender, age (in } \\
\text { 2014), } \\
\text { education, } \\
\text { caste and } \\
\text { religion }\end{array}$ & $\begin{array}{c}\text { Role in } \\
\text { microcredit } \\
\text { organisations and } \\
\text { main occupation } \\
\text { (for SHG leaders) }\end{array}$ & Networks & Additional services & $\begin{array}{l}\text { Accumulation } \\
\text { (rough estimate) }\end{array}$ \\
\hline $\begin{array}{l}\mathrm{F} 8 \text {, Female } \\
45 \text { years old } \\
\text { Knows how to } \\
\text { write and } \\
\text { read } \\
\text { Dalit Hindu }\end{array}$ & $\begin{array}{l}\text { SHG leader } \\
\text { Agriculture and } \\
\text { moneylending }\end{array}$ & $\begin{array}{l}\text { Strong connections with the } \\
\text { two main political parties } \\
\text { and contractors (through } \\
\text { her husband who is } \\
\text { village government } \\
\text { president) }\end{array}$ & $\begin{array}{l}\text { Government schemes and } \\
\text { administrative paper } \\
\text { work } \\
\text { Moneylending }\end{array}$ & $\begin{array}{l}\text { Moneylending: } \\
\text { net profit of } \\
45,000 \text { per } \\
\text { month (2013) }\end{array}$ \\
\hline $\begin{array}{l}\text { F9, Female } \\
40 \text { years old } \\
\text { Knows how to } \\
\text { read and } \\
\text { write } \\
\text { Dalit Hindu }\end{array}$ & $\begin{array}{l}\text { SHG leader } \\
\text { Moneylending }\end{array}$ & $\begin{array}{l}\text { Her parents were the first to } \\
\text { settle in the hamlet } \\
\text { Strong local female } \\
\text { network thanks to her } \\
\text { past experience as } \\
\text { Rosca's manager and } \\
\text { saree seller } \\
\text { Network with local } \\
\text { administrations, village } \\
\text { government president, } \\
\text { local representatives of } \\
\text { various political parties, } \\
\text { moneylenders }\end{array}$ & $\begin{array}{l}\text { Government schemes and } \\
\text { administrative paper } \\
\text { work } \\
\text { Advice for health services, } \\
\text { legal issues, personal } \\
\text { matters } \\
\text { Roscas (stopped in 2008) } \\
\text { Moneylending }\end{array}$ & $\begin{array}{l}\text { Moneylending: } \\
\text { net profit of } \\
1000 \text { to } 3000 \\
\text { INR per month } \\
\text { (2013) }\end{array}$ \\
\hline $\begin{array}{l}\text { F10, Female } \\
40 \text { years old } \\
\text { Knows how to } \\
\quad \text { read and } \\
\text { write } \\
\text { Dalit Christian } \\
\text { (protestant) }\end{array}$ & $\begin{array}{l}\text { SHG leader } \\
\text { Child care } \\
\text { assistant }\end{array}$ & $\begin{array}{l}\text { Through her job (child care } \\
\text { assistant in a crèche), she } \\
\text { has developed a strong } \\
\text { local network with } \\
\text { women } \\
\text { Her job also allows her to } \\
\text { access information from } \\
\text { the local village } \\
\text { government and from } \\
\text { local administrations } \\
\text { Connected to the political } \\
\text { party DMK (one of the } \\
\text { two main ruling parties) }\end{array}$ & $\begin{array}{l}\text { Government schemes and } \\
\text { administrative paper } \\
\text { work } \\
\text { Moneylending } \\
\text { Advice on personal matters }\end{array}$ & $\begin{array}{l}\text { Moneylending: } \\
\text { net profit of } \\
500 \text { to } 1000 \\
\text { INR per month } \\
\text { (2013) }\end{array}$ \\
\hline $\begin{array}{l}\text { F11, Female } \\
40 \text { years old } \\
\text { Studied till } 8^{\text {th }} \\
\text { standard } \\
\text { Middle caste } \\
\text { (Vanniyar), } \\
\text { Hindu }\end{array}$ & $\begin{array}{l}\text { SHG leader } \\
\text { Runs a business } \\
\text { centre }\end{array}$ & $\begin{array}{l}\text { Through her own business, } \\
\text { she has built a network } \\
\text { with local shops, } \\
\text { financers, administration }\end{array}$ & $\begin{array}{l}\text { Regularly solves problems } \\
\text { for other women } \\
\text { entrepreneurs (with the } \\
\text { administration, their } \\
\text { providers or their clients) } \\
\text { She facilitates access to } \\
\text { goods and services at a } \\
\text { lower price } \\
\text { Advice on personal matters } \\
\text { Helps with money transfers } \\
\text { between town and } \\
\text { village (as she lives in a } \\
\text { village but works in } \\
\text { town) }\end{array}$ & $\begin{array}{l}\text { Moneylending: } \\
\text { net profit of } \\
1000 \text { to } 2000 \\
\text { INR per month } \\
\text { (2013) }\end{array}$ \\
\hline
\end{tabular}


Table A.5. (Continued)

\begin{tabular}{|c|c|c|c|c|}
\hline $\begin{array}{l}\text { Gender, age (in } \\
\text { 2014), } \\
\text { education, } \\
\text { caste and } \\
\text { religion }\end{array}$ & $\begin{array}{c}\text { Role in } \\
\text { microcredit } \\
\text { organisations and } \\
\text { main occupation } \\
\text { (for SHG leaders) }\end{array}$ & Networks & Additional services & $\begin{array}{l}\text { Accumulation } \\
\text { (rough estimate) }\end{array}$ \\
\hline $\begin{array}{l}\text { F12, Female } \\
35 \text { years old } \\
\text { Knows how to } \\
\quad \text { read and } \\
\quad \text { write } \\
\text { Dalit Christian } \\
\quad \text { (protestant) }\end{array}$ & $\begin{array}{l}\text { SHG leader } \\
\text { No regular } \\
\text { occupation }\end{array}$ & $\begin{array}{l}\text { Strongly committed in the } \\
\text { Lutheran church } \\
\text { Network with schools }\end{array}$ & $\begin{array}{l}\text { Access to government } \\
\text { schemes } \\
\text { Health services } \\
\text { Advice on school } \\
\text { Specific support for women } \\
\text { who experience great } \\
\text { difficulties (preparing } \\
\text { food, child care) } \\
\text { Accompany women in their } \\
\text { prayers }\end{array}$ & $\begin{array}{l}\text { Lends from time } \\
\text { to time from } \\
\text { her own pocket } \\
\text { but for limited } \\
\text { amounts }\end{array}$ \\
\hline $\begin{array}{l}\text { F13, Female } \\
45 \text { years old } \\
\text { Knows how to } \\
\text { read and } \\
\text { write } \\
\text { Dalit Hindu }\end{array}$ & $\begin{array}{l}\text { SHG leader } \\
\text { Labour contractor } \\
\text { (for sugar cane } \\
\text { cutting) }\end{array}$ & $\begin{array}{l}\text { Good connections with } \\
\text { local administrations (her } \\
\text { husband has a permanent } \\
\text { job in government } \\
\text { office) } \\
\text { Good connections with } \\
\text { employers }\end{array}$ & $\begin{array}{l}\text { Access to government } \\
\text { schemes } \\
\text { Labour } \\
\text { Helps in case of emergency } \\
\text { (hospitalisation, child } \\
\text { care) } \\
\text { Accompany women when } \\
\text { needed, acts as a moral } \\
\text { guarantor for men }\end{array}$ & No \\
\hline $\begin{array}{l}\text { F14, Female } \\
46 \text { years old } \\
\text { Primary } \\
\text { education } \\
\text { Dalit Hindu }\end{array}$ & $\begin{array}{l}\text { SHG leader } \\
\text { 'Traditional' } \\
\text { midwife }\end{array}$ & $\begin{array}{l}\text { Good connections with } \\
\text { health centres }\end{array}$ & $\begin{array}{l}\text { Health services (especially } \\
\text { related to pregnancy, } \\
\text { abortion and delivery) } \\
\text { Engaged in collective } \\
\text { claims related to road } \\
\text { and water facilities }\end{array}$ & $\begin{array}{l}\text { Lends from time } \\
\text { to time from } \\
\text { her own pocket } \\
\text { but for limited } \\
\text { amounts }\end{array}$ \\
\hline $\begin{array}{l}\text { F15, Female } \\
\text { Around } 40 \\
\text { years old } \\
\text { Knows how to } \\
\text { read and } \\
\text { write } \\
\text { Dalit }\end{array}$ & $\begin{array}{l}\text { SHG leader } \\
\text { Labour recruiter } \\
\text { for brick kilns }\end{array}$ & $\begin{array}{l}\text { Good connections with } \\
\text { employers }\end{array}$ & $\begin{array}{l}\text { Labour } \\
\text { Moneylending } \\
\text { Advice on personal matters }\end{array}$ & $\begin{array}{l}\text { Moneylending: } \\
\text { net profit of } \\
1000 \text { to } 2000 \\
\text { INR per month } \\
\text { (2013) }\end{array}$ \\
\hline $\begin{array}{l}\text { F16, Female } \\
38 \text { years old } \\
\text { Knows how to } \\
\text { read and } \\
\text { write } \\
\text { (Middle Caste) } \\
\text { Vanniyar } \\
\text { Hindu }\end{array}$ & $\begin{array}{l}\text { SHG leader } \\
\text { Bank agent } \\
\text { Moneylender }\end{array}$ & $\begin{array}{l}\text { Good networks with banks } \\
\text { and moneylenders }\end{array}$ & $\begin{array}{l}\text { Moneylending } \\
\text { Administrative paper work } \\
\text { Free evening school for the } \\
\text { children } \\
\text { Transport (she has a } \\
\text { motorbike) } \\
\text { Advice on personal matters }\end{array}$ & $\begin{array}{l}\text { Moneylending: } \\
\text { net profit of } \\
3000 \text { to } 6000 \\
\text { INR per month } \\
\text { (2013) }\end{array}$ \\
\hline $\begin{array}{l}\text { F17, Female } \\
40 \text { years old } \\
\text { Primary } \\
\text { Education } \\
\text { Middle caste } \\
\text { (Vanniyar) }\end{array}$ & $\begin{array}{l}\text { SHG leader } \\
\text { Runs a small } \\
\text { business }\end{array}$ & $\begin{array}{l}\text { Close connections with the } \\
\text { PMK (which is the } \\
\text { Vanniyar Party) }\end{array}$ & $\begin{array}{l}\text { Regularly acts a mediator } \\
\text { between women and } \\
\text { NGO, women } \\
\text { entrepreneurs and the } \\
\text { police (negotiating over } \\
\text { bribes, licences, eviction } \\
\text { threats, and so forth) }\end{array}$ & $\begin{array}{l}\text { Information not } \\
\text { available }\end{array}$ \\
\hline
\end{tabular}

